\title{
Human complement activation by smooth and rough Proteus mirabilis lipopolysaccharides
}

\section{Wiesław Kaca1, 2, Michał Arabski², Rafał Fudała², Eva Holmström³ ${ }^{3}$, Anders Sjöholm³, Andrej Weintraub ${ }^{1}$, Bożena Futoma-Kołoch ${ }^{4}$, Gabriela Bugla-Płoskońska ${ }^{4}$ and Włodzimierz Doroszkiewicz ${ }^{4}$}

${ }^{1}$ Division of Clinical Bacteriology, Huddinge University Hospital, Karolinska Institute, Huddinge, Sweden

2 Department of Microbiology, Institute of Biology, Jan Kochanowski University, Kielce, Poland

${ }^{3}$ Division of Microbiology, Immunology, and Glycobiology, Lund University, Lund, Sweden

${ }^{4}$ Institute of Genetics and Microbiology, Wrocław University, Wrocław, Poland

Received: 2008.09.18, Accepted: 2009.03.31, Published online: 2009.08.18

(C) L. Hirszfeld Institute of Immunology and Experimental Therapy, Wrocław, Poland 2009

\begin{abstract}
Introduction: Proteus mirabilis bacilli play an important role in human urinary tract infections, bacteremia, and rheumatoid arthritis. The authors previously studied human complement $\mathrm{C} 3$ conversion by smooth-form P. mirabilis O10, O23, O30, and O43 lipopolysaccharides (LPSs) and showed that smooth Proteus LPSs fragmented C3 in a dose- and time-dependent manner. In the present study, one smooth P. mirabilis S1959 and its two polysaccharide-truncated LPSs isolated from an R mutant strain were used to study the $\mathrm{C} 3$ conversion.

Materials and Methods: The conversion of C3 to C3c by smooth and rough P. mirabilis LPSs was studied by capture ELISA and crossed immunoelectrophoresis. Proteins isolated from the outer membrane were analyzed by discontinuous sodium dodecyl sulfate gel electrophoresis.

Results: The smooth $P$. mirabilis S1959 (O3) strain was resistant to the bactericidal activity of human serum, in contrast to the $\mathrm{Ra}$ and $\mathrm{Re}$ mutant strains. The presence of an exposed core oligosaccharide in R110 LPS was not sufficient to protect the strain from serum-dependent killing. In addition to LPS structure, the outer-membrane proteins may also play roles in protecting the smooth $P$. mirabilis S1959 (O3) strain from the bactericidal action of serum. It was shown that the Ra $P$. mirabilis R110 and the Re $P$. mirabilis R45 mutants possess very different OMP compositions from that of the $P$. mirabilis $\mathrm{S}$ 1959 strain.

Conclusion: Regardless of the complement resistance of the P. mirabilis strains, the S1959, R110, and R45 LPSs fragmented C3 and induced C3c neo-antigen exposure. The use of complement-deficient human serum allows the conclusion that the Re-type $P$. mirabilis R45 LPS fragmented C3 by the antibody-independent classical pathway.
\end{abstract}

Key words: Proteus mirabilis, complement, lipopolysaccharide, outer-membrane protein.

Corresponding author: Michał Arabski, Ph.D., Department of Microbiology, Institute of Biology, Jan Kochanowski University, Świętokrzyska 15, 25-406 Kielce, Poland, tel.: +48 41-3496308, fax: + 48 41-3496292, e-mail: arabski@ujk.kielce.pl

\section{INTRODUCTION}

One of the functions of the complement (C) system in host defense is self/non-self recognition (Blatteis et al. 2004; Vukajlovich et al. 1987). The lipopolysaccharides (LPSs) and outer-membrane proteins (OMPs) located on the outer membrane of Gram-negative bacteria are important targets for the bactericidal action of the complement system (Biedzka-Sarek et al. 2005; Blatteis et al. 2004; Hostetter 1993; Vukajlovich et al.
1987). The structure of the O-specific side chain of LPS and any structural change in or chemical modification of it play important roles in the resistance of bacterial cells to the lytic activity of complement (Lachowicz and Doroszkiewicz 1996; Lachowicz et al. 1999; Taylor 1992). OMPs are probably responsible for the different levels of sensitivity of some Gram-negative strains to the bactericidal activity of complement (Cisowska et al. 2005; Futoma-Kołoch et al. 2006; Pilz et al. 1992). 
There are different mechanisms of LPS-mediated complement activation. The antibody-independent classical pathway (CP) is mediated only by the lipid A portion of the molecule. Activation of the alternative pathway requires polysaccharide moieties of LPS: core oligosaccharide and/or O-antigen polysaccharides (Besucher and Brade 1986; Biedzka-Sarek et al. 2005; Gardiner et al. 1991; Vukajlovich et al. 1987). Poly-saccharides are also required by the lectin pathways of complement activation with involvement of mannose-binding protein (MBP) (Chonn et al. 1991; Ohta et al. 1990). The C3 molecules play a pivotal role in the junctions of the three pathways of complement activation (Becherer et al. 1990; Hostetter 1993; Hostetter and Gordon 1987). The C3 moieties link the different complement pathways of activation and C3's fragmentation in serum give rises to $\mathrm{C} 3 \mathrm{a}, \mathrm{C} 3 \mathrm{~b}, \mathrm{iC} 3 \mathrm{~b}, \mathrm{C} 3 \mathrm{c}$, and $\mathrm{C} 3 \mathrm{~d}$ (Becherer et al. 1990; Hostetter and Gordon 1987). Complement activation starts the inflammatory processes, which in some cases may end with the deteriorating effects of overreactions, as observed in endotoxin shock (Blatteis et al. 2004; Hostetter 1993). Complement activation and C3 fragmentation by Proteus mirabilis S and R LPSs may enhance the inflammatory response.

P. mirabilis bacilli play an important role in human urinary tract infections, bacteremia, and rheumatoid arthritis (Różalski et al. 1997). We previously studied C3 conversion by smooth-form $P$. mirabilis $\mathrm{O} 10, \mathrm{O} 23$, O30, and O43 LPSs (Kaca et al. 2000). We showed that smooth Proteus LPSs fragmented C3 in a dose- and time-dependent manner (Kaca et al. 2000). In the present study, one smooth P. mirabilis $\mathrm{S} 1959$ and its two polysaccharide-truncated LPSs isolated from an R mutant strain were used to study $\mathrm{C} 3$ conversion. The P. mirabilis $\mathrm{S} 1959$ strain was classified to the $\mathrm{O} 3$ serogroup and its O-polysaccharide chain is built up of pentasaccharide repeating units with amidically linked lysine residues (Amano et al. 1996; Ziółkowski et al. 1997). The polymer of the pentasaccharide repeating units of the $\mathrm{O} 3$-antigen is attached to a core oligosaccharide characterized by the presence of D-galacturonic acid residues in both the terminal and inter-chain positions (Vinogradov et al. 2000). By chemical mutation of the parent smooth P. mirabilis S1959 strain, two mutants producing polysaccharide-truncated LPSs were isolated. The $P$. mirabilis $\mathrm{R} 110$ strain produces Ra-type LPS with a complete core oligosaccharide, but lacks the O-antigen (Vinogradov et al. 2000). The $P$. mirabilis $\mathrm{R} 45$ strain contains a truncated core oligosaccharide (Re-type) LPS (Amano et al. 1996; Różalski et al. 1997; Vinogradov et al. 2000; Vinogradov et al. 1994; Ziółkowski et al. 1997). We tried to correlate $\mathrm{C} 3$ fragmentation with complement-mediated bacteriolysis and the role of the core and O-polysaccharide parts of the P. mirabilis LPSs in these reactions. We also determined the electrophoretic patterns of OMPs isolated from P. mirabilis S1959 and its two R LPS mutants.

\section{MATERIALS AND METHODS}

\section{Bacteria and growth conditions}

P. mirabilis O10, $\mathrm{S} 1959$ (OXK, O3), and its two $\mathrm{R}$ mutants Ra (R110) and Re (R45) were obtained from the Institute of Microbiology and Immunology, University of Łódź, Poland. The bacteria were cultivated under aerobic conditions in nutrient broth. The complete structures of the lipid A portion, core oligosaccharide, and O-polysaccharide of the S1959, R110, and R45 LPSs were presented previously (Amano et al. 1996; Różalski et al. 1997; Vinogradov et al. 2000; Vinogradov et al. 1994; Ziółkowski et al. 1997).

\section{Lipopolysaccharides}

Lipopolysaccharides were isolated from the smooth Proteus strains by the hot phenol-water extraction method (Westphal and Jann 1965). The Proteus LPSs of $\mathrm{R}$ form were extracted by the phenol-chloroform-petroleum ether method (Galanos et al. 1969). The LPSs were purified by DNase and RNase (Sigma Chemical Co. St. Louis, MO, USA) treatment and ultracentrifugation, as described (Amano et al. 1996; Ziółkowski et al. 1997). All LPSs were essentially free of nucleic acids and contained less than $2 \%$ proteins. Delipidation of LPS was performed using $1 \%$ acetic acid at $100^{\circ} \mathrm{C}$ until lipid A precipitated. The insoluble lipid fraction was pelletted by centrifugation $(15,000 \times \mathrm{g}$ for $60 \mathrm{~min})$. The supernatant was fractionated on a Sephadex G-50 column (Pharmacia Fine Chemicals, Uppsala, Sweden). The O-specific polysaccharide (F1 fraction) and the core oligosaccharide (F2 fraction) were eluted with 0.05 $\mathrm{M}$ pyridine acetate buffer, $\mathrm{pH}$ 4.5. The triethylamine salt of Salmonella minnesota 595 LPS was from stock at the Division of Clinical Bacteriology, Karolinska Institute, Huddinge University Hospital, Huddinge, Sweden.

\section{Complement}

Blood samples were taken from healthy donors by vein puncture and collected into dry vacutainer tubes. The samples were allowed to clot for about $1 \mathrm{~h}$ at room temperature and centrifuged at $4^{\circ} \mathrm{C}$. The serum was frozen in liquid nitrogen and stored in 0.2-ml aliquots at $-70^{\circ} \mathrm{C}$ until tested (Andersson et al. 2005). Complement-deficient serum was from the Department of Medical Microbiology, Section of Clinical Immunology, Lund University, Lund, Sweden. The serum depletion procedures were described previously (Fredrikson et al. 1999; Johnson and Holmström 1982; Sjöholm et al. 1982). In the complement-deficient serum the classical, lectin, and alternative pathways did not function due to the depletion of antibodies, P, D, and MBL complement proteins (Fredrikson et al. 1999; Johnson and Holmström 1982; Sjöholm et al. 1982). To this deficient serum was added C1q (10\% of the normal 
amount). Therefore the antibody-independent classical pathway of activation was restored and this serum was designated as C1qD. The serum antibody titer of antiS1959, -R110, and -R45 LPS was 1:100, measured by enzyme-linked immunosorbent assay (ELISA). In the C1qD complement-deficient serum, anti- $P$. mirabilis LPS antibodies were not detected.

\section{Hemolytic complement assay}

Complement fixation was determined by lysis of sensitized sheep red blood cells by antibodies as described (Kaca and Roth 1995). V-bottomed microtiter plates (NUNC, Denmark) were used. Serial dilutions of bacterial dry masses or LPS in veronal buffer (VB, $50 \mu \mathrm{l}), \mathrm{pH}$ 7.4, $0.15 \mathrm{mM} \mathrm{CaCl}_{2}, 1 \mathrm{mM} \mathrm{MgCl}_{2}$, and $0.01 \%$ gelatin (Ohta et al. 1990) were incubated for $30 \mathrm{~min}$ at $37^{\circ} \mathrm{C}$ with $50 \mu \mathrm{l}$ of serum (Sigma) 1:5 diluted in $\mathrm{VBMgCa}$. This dilution is sufficient to produce $60-80 \%$ lysis of the erythrocytes. Mixtures of LPS and serum were incubated for $60 \mathrm{~min}$ at $37^{\circ} \mathrm{C}$ under gentle mixing with $50 \mathrm{ml}$ of sensitized sheep erythrocytes and unlysed erythrocytes were pelleted $(3000 \times \mathrm{g}$ for $15 \mathrm{~min})$. Ninety $\mathrm{ml}$ of the supernatants were transferred to flat-bottom Costar microtiter plates and the quantity of free hemoglobin was measured at $405 \mathrm{~nm}$ using a multichannel plate reader (Multiscan). Replicate wells (3-8) were run for each experimental sample and each experiment was repeated at least two times. Representative results are shown.

\section{C3 conversion detected by capture ELISA}

ELISA measurements of C3 conversion to lower-molecular-mass fragments were based on a method described by Holmskov-Nielsen (Holmskov-Nielsen et al. 1986; Garred et al 1988). The assay detects (relative to the control) $\mathrm{C} 3 \mathrm{c}$ neo-determinant increases in $\mathrm{C} 3$ low-molecular-mass fragments after C3 fragmentation by exposure to complement-activating agents. The method was run as described by us previously (Kaca et al. 2000). The human serum and LPS $(10 \mu \mathrm{g} / \mathrm{ml})$ were incubated for $45 \mathrm{~min}$ at $37^{\circ} \mathrm{C}$ and the reaction was stopped by $1 / 2000$ dilution in ice-cold phosphate buffer saline (PBS) supplemented with $10 \mathrm{mM}$ EDTA and $0.2 \%$ Tween. Then the diluted mixtures of serum and LPS were transferred to plates (flat-bottom high-binding Costar, Cambridge, USA) pre-coated for $2 \mathrm{~h}$ at $37^{\circ} \mathrm{C}$ with rabbit anti-human $\mathrm{C} 3 \mathrm{c}$ antibodies (DAKO $\mathrm{A} / \mathrm{S}$, Denmark) diluted $1 / 500$ in $0.1 \mathrm{M}$ sodium carbonate buffer, $\mathrm{pH}$ 9.6. The pre-coated plates with diluted mixtures of serum and LPS were incubated for $2 \mathrm{~h}$ at $10^{\circ} \mathrm{C}$ and the amounts of captured $\mathrm{C} 3 \mathrm{c}$ fragments were then detected by incubation for $30 \mathrm{~min}$ at $37^{\circ} \mathrm{C}$ with secondary horseradish peroxidase-conjugated rabbit anti-human C3c antibodies (DAKO A/S, Denmark, diluted $1 / 2000$ in PBS, $1 \%$ BSA, and $0.2 \%$ Tween). After each step the plates were washed eight times with PBS (Titrek microplate washer, M96V, ICN Flow, England). The enzyme activity remaining in the wells was deter- mined by adding $0.1 \mathrm{ml}$ OPD (1,2-phenylenediamine dichloride, DAKO A/S, Denmark) solution. After 10 min at room temperature the reaction was stopped by $0.1 \mathrm{ml}$ of $0.5 \mathrm{M} \mathrm{H}_{2} \mathrm{SO}_{4}$. The absorbance at $492 \mathrm{~nm}$ was read using a multichannel spectrophotometer (Labsystems Multiscan Plus, Finland). As a negative control, serum alone or heat-inactivated serum (30 min, $56^{\circ} \mathrm{C}$ ) was used in each experiment. Three to nine replicate wells were run for each experimental sample and each experiment was repeated at last three times.

\section{Crossed immunoelectrophoresis}

Human C3 conversion was detected with crossed immunoelectrophoresis, as previously described (Johnson and Holmström 1982). The human complement, diluted to $90 \%$ in PBS, was activated by LPS (10 $\mu \mathrm{g} / \mathrm{ml}$ ) at $37^{\circ} \mathrm{C}$ for $15 \mathrm{~min}$. The reaction was stopped by dilution in ice-cold PBS supplemented with $10 \mathrm{mM}$ EDTA. The human complement proteins were separated first by agarose gel $(0.6 \%$, Seakem, FMC, USA) electrophoresis $(1 \mathrm{~V} / \mathrm{cm})$ in $0.075 \mathrm{M}$ veronal buffer supplemented with $2 \mathrm{mM}$ EDTA for $1 \mathrm{hr}$ at $8^{\circ} \mathrm{C}$. The proteins separated by the first electrophoresis were transferred to a second agarose gel containing $0.6 \%$ rabbit antihuman C3c (DAKO A/S, Denmark). The second electrophoresis was performed at $1 \mathrm{~V} / \mathrm{cm}$ for $3 \mathrm{~h}$ and the gels were pressed and fixed and the precipitates stained with Coomassie blue $(0.5 \%)$.

\section{Isolation of the OMPs (with modification)}

The OMPs were isolated from bacteria grown in 100 $\mathrm{ml}$ of brain-heart infusion broth (Difco) at $37^{\circ} \mathrm{C}$ for $18 \mathrm{~h}$ (Murphy and Bartos 1989). After incubation the bacterial cells were centrifuged ( $4000 \mathrm{rpm}$ at $4^{\circ} \mathrm{C}$ for $20 \mathrm{~min}$ ) and the pellet was suspended in $2.5 \mathrm{ml}$ of buffer B (1 M sodium acetate, $0.001 \mathrm{M} \beta$-mercaptoethanol, $\mathrm{pH} 4.0)$. Then a $22.5-\mathrm{ml}$ water solution containing $5 \%$ Zwittergent Z 3-14 (Calbiochem-Behring) and $0.5 \mathrm{M} \mathrm{CaCl}_{2}$ was added. This mixture was stirred at room temperature for $1 \mathrm{~h}$. To precipitate nucleic acids, $6.25 \mathrm{ml}$ of $96 \%$ cold ethanol was added very slowly. The mixture was then centrifuged at $12,300 \mathrm{rpm}$ at $4^{\circ} \mathrm{C}$ for $10 \mathrm{~min}$. The remaining proteins were precipitated by the addition of $93.5 \mathrm{ml}$ of $96 \%$ cold ethanol and centrifuged at 12,300 $\mathrm{rpm}$ at $4^{\circ} \mathrm{C}$ for $20 \mathrm{~min}$. The pellet was suspended in $5 \mathrm{ml}$ of buffer Z (0.05\% Zwittergent, 0.05 M Tris, and 0.01 M EDTA, pH 8.0) and stirred at room temperature for $1 \mathrm{~h}$. The solution was kept at $4^{\circ} \mathrm{C}$ overnight and centrifuged at $8700 \mathrm{rpm}$ at $4^{\circ} \mathrm{C}$ for $10 \mathrm{~min}$. OMPs were presented in the buffer $\mathrm{Z}$ soluble fraction after centrifugation. The Bradford protein assay was used to measure the concentration of proteins in the samples (Bradford 1976).

\section{Polyacrylamide gel electrophoresis}

Discontinuous sodium dodecyl sulfate gel electrophoresis (SDS-PAGE) was carried out on slabs with 
12.5\% acrylamide according to Laemmli (Laemmli 1970). The OMPs prepared in the sample buffer were loaded in each of the wells at the same volume of $10 \mu$. The samples were applied to slabs after heating at $100^{\circ} \mathrm{C}$ for $4 \mathrm{~min}$ with sample buffer. The Wide Molecular Weight Range Sigma Marker protein standard (twelve proteins from 6-205 kDa) was used for molecular-mass calibration. Electrophoresis was carried out at $100 \mathrm{~V}$ for $15 \mathrm{~min}$ and then at $200 \mathrm{~V}$ for $45 \mathrm{~min}$. When electrophoresis was completed, the gels were kept for $1 \mathrm{~h}$ in a solution containing $25 \%$ methanol, $10 \%$ acetic acid, and $0.05 \%$ Coomassie brilliant blue and destained in 10\% acetic acid for 3-5 h. The molecular masses of the OMP's were analyzed with Quantity One v. 4.0.1 software.

\section{Complement-mediated bactericidal assay}

Proteus strains were grown overnight in Mueller-Hinton broth. When the cultures reached an absorbence of 0.6 at $640 \mathrm{~nm}\left(\mathrm{~A}_{640}\right)$, they were diluted in PBS in V-bottomed microtiter plates (NUNC, Denmark) to about 100 cells per well. The number of bacterial cells was confirmed by the colony forming units (CFU) plate method. Reaction mixtures were prepared by combining $25 \mu \mathrm{l}$ of the bacterial suspension and $75 \mu \mathrm{l}$ of human sera. Bacterial cells with sera were incubated for 5,30 , and $60 \mathrm{~min}$ at $37^{\circ} \mathrm{C}$ with shaking and then $100 \mu \mathrm{l}$ of cold Mueller-Hinton broth was added. Resistant bacterial cells were cultivated for $16 \mathrm{~h}$ at $37^{\circ} \mathrm{C}$ with shaking and then sedimented $(3000 \times \mathrm{g}$ for $15 \mathrm{~min})$. The bactericidal activities of the serum were evaluated in reactions containing active serum (intact complement source, C), heat-inactivated serum $\left(50^{\circ} \mathrm{C}\right.$ for $20 \mathrm{~min}$, alternative pathway inactivated, classical active, $\mathrm{C}-\mathrm{CP}$ ), and in the control samples containing inactive complement (C-In, $30 \mathrm{~min}$ at $56^{\circ} \mathrm{C}$ ) (Kaca et al. 2000; Vukajlovich et al. 1987). Three replicate wells were run for each experimental sample and each experiment was repeated at last three times. Representative results are presented. The bacteriocidal assays on microtiter plates were confirmed by the plate method, as described (Futoma-Kołoch et al. 2006).

\section{RESULTS}

Complement-mediated bactericidal effect on smooth and rough P. mirabilis strains

The complement-mediated bactericidal effect was tested under conditions in which only a few bacterial cells (about 100) were exposed to the serial human serum dilutions (Table 1). This condition resembles the natural way of invasion, in which few bacteria enter the blood vessels. The native serum diluted up to $0.15 \%$ killed the $P$. mirabilis $\mathrm{Ra}$ and $\mathrm{Re}$ mutants. The smooth S1959 cells were resistant in all the serum dilutions used. Five-minute incubation at $37^{\circ} \mathrm{C}$ with the native $\mathrm{C}$ and

Table 1. The bactericidal effect of human sera on the P. mirabilis S1959, R110, and R45 strains

\begin{tabular}{|c|c|c|c|c|c|c|c|c|c|c|c|c|}
\hline \multirow[t]{2}{*}{ LPS } & \multirow[t]{2}{*}{ Serum } & \multirow{2}{*}{$\begin{array}{l}\text { Time } \\
(\min )\end{array}$} & \multicolumn{10}{|c|}{ Serum dilution $(\%)$} \\
\hline & & & 75 & 50 & 10 & 5 & 2.5 & 1.25 & 0.62 & 0.31 & 0.15 & 0.07 \\
\hline \multirow[t]{5}{*}{ S1959 } & $\mathrm{C}$ & 5 & $+* *$ & + & + & + & + & + & + & + & + & + \\
\hline & & 30 & + & + & + & + & + & + & + & + & + & + \\
\hline & & 60 & + & + & + & + & + & + & + & + & + & + \\
\hline & $\mathrm{C}-\mathrm{CP}$ & 60 & + & + & + & + & + & + & + & + & + & + \\
\hline & C-In & 60 & + & + & + & + & + & + & + & + & + & + \\
\hline \multirow[t]{5}{*}{ R110 } & $\mathrm{C}$ & 5 & $-*$ & - & - & - & - & - & - & - & + & + \\
\hline & & 30 & - & - & - & - & - & - & - & - & + & + \\
\hline & & 60 & - & - & - & - & - & - & - & - & + & + \\
\hline & C-CP & 60 & - & - & - & - & - & + & + & + & + & + \\
\hline & C-In & 60 & + & + & + & + & + & + & + & + & + & + \\
\hline \multirow[t]{5}{*}{ R45 } & $\mathrm{C}$ & 5 & - & - & - & - & - & - & - & - & + & + \\
\hline & & 30 & - & - & - & - & - & - & - & - & + & + \\
\hline & & 60 & - & - & - & - & - & - & - & - & + & + \\
\hline & C-CP & 60 & - & - & - & - & - & + & + & + & + & + \\
\hline & C-In & 60 & + & + & + & + & + & + & + & + & + & + \\
\hline
\end{tabular}

\footnotetext{
* No traces of bacterial sediment. ** Sediment of bacteria after 5,30 , and $60 \mathrm{~min}$ of incubation at $37^{\circ} \mathrm{C}$. C - native serum (complement active), $\mathrm{C}-\mathrm{CP}$ - heat-inactivated serum at $50^{\circ} \mathrm{C}$ for $20 \mathrm{~min}$. (CP - classical pathway inactive, alternative pathway of complement active), C-In - heat-inactivated serum at $56^{\circ} \mathrm{C}$ for $30 \mathrm{~min}$ (copmplement inactive). The samples were run in duplicate and repeated at least three times. Representative results are presented.
} 
C-CP sera was sufficient to kill the $\mathrm{R}$ mutants (Table 1). The micotiter plate results were confirmed by the CFU plate method. The number of $P$. mirabilis S1959 cells increased from $2 \times 10^{7}$ to $5 \times 10^{7}$ after 60 min of incubation in the $50 \%$ human $\mathrm{C}$ dilution. That is in agreement with previously published data (Futoma-Kołoch et al. 2006). In contrast to the smooth S1959 strain, the two R mutant strains were sensitive to the bactericidal action and did not grow in native $\mathrm{C}$ and $\mathrm{C}-\mathrm{CP}$ diluted to $50 \%$ in PBS. This indicates that the classical pathway of complement activation plays an important role in preventing the growth of the $P$. mirabilis R110 and R45 mutant strains. The presence of the O-polysaccharide of LPS on the surface of the $P$. mirabilis S1959 strain protected that strain from the bactericidal action of human serum. The presence of the core oligosaccharide of LPS on the P. mirabilis R110 strain was not sufficient to the prevent the bactericidal effect of complement. In the next experiment the role of the OMPs of P. mirabilis S1959, R110, and R45 in complement-mediated killing was tested.

\section{Electrophoretic patterns of OMPs of smooth and rough P. mirabilis cells}

The Bradford protein assay showed that the three tested $P$. mirabilis strains contained similar amounts of OMPs, i.e. 1.2, 0.9, and $1.1 \mathrm{mg} / \mathrm{ml}$ for the S1959, R110, and R45 cells, respectively. The OMPs of the P. mirabilis S1959 strain and its R forms were isolated and analyzed using SDS-PAGE. The analysis, presented in Fig. 1, shows that there are differences between $P$. mirabilis S1959 and its LPS mutant forms with regard to OMP expression. The $P$. mirabilis $\mathrm{S} 1959$ strain, which is resistant to the bactericidal action of human serum, possessed only ten OMPs, with the 36-, 24-, and 18-kDa proteins predominating. The Ra (R110) and Re (R45) mutants contained 22 and 21 OMPs, respectively (Fig. 1 ). The two R mutants differed by the presence of 116-,
40-, 39-, and 19-kDa proteins. These R mutants produced several proteins in excess which were in lower quantities than those isolated from the serum-resistant strain P. mirabilis S 1959. It is worth mentioning that we observed hyperproduction of 33- and 35-kDa OMPs by the Ra (R110) and of 33-kDa OMP by the Re (R45) LPS mutants. These proteins were not present in the $P$. mirabilis S1959 strain. The presence and ratios of OMPs in concert with the composition of the LPSs may play an essential role in protecting the $P$. mirabilis rods from the bactericidal action of human complement.

\section{Complement binding and C3 fragmentation by $P$. mirabilis $S$ and $R$ LPSS}

In the next set of experiments we tried to find whether complement-mediated $P$. mirabilis lysis is accompanied by $\mathrm{C}$ binding and $\mathrm{C} 3$ fragmentation. Complement fixation by lyophilized cells of the $P$. $m i$ rabilis $\mathrm{S} 1959$ smooth strain and the two rough mutants and their respective LPSs were tested with sensitized sheep erythrocytes. The fixation of human complement proteins, Proteus cells and erythrocytes resulted in hemoglobin release (Fig. 2A). The P. mirabilis R 45 ( Re type) lyophilized cells were much less potent in complement fixation than the R 110 (Ra type) and S1959 (smooth type) cells (Fig. 3A). This may be due to the differences in OMPs and the composition of the polysaccharide part of the LPSs. LPSs were isolated from the smooth $P$. mirabilis $\mathrm{S} 1959$ and the two mutant strains and the human complement-binding abilities were tested (Fig. 2B). In contrast to the P. mirabilis S1959 lyophilized cells, the isolated S1959 LPS was not effective in human complement fixation. The R110 LPS had reduced complement fixation abilities compared with R45 LPS. This suggests that the complete core of R110 LPS prevented these activities.

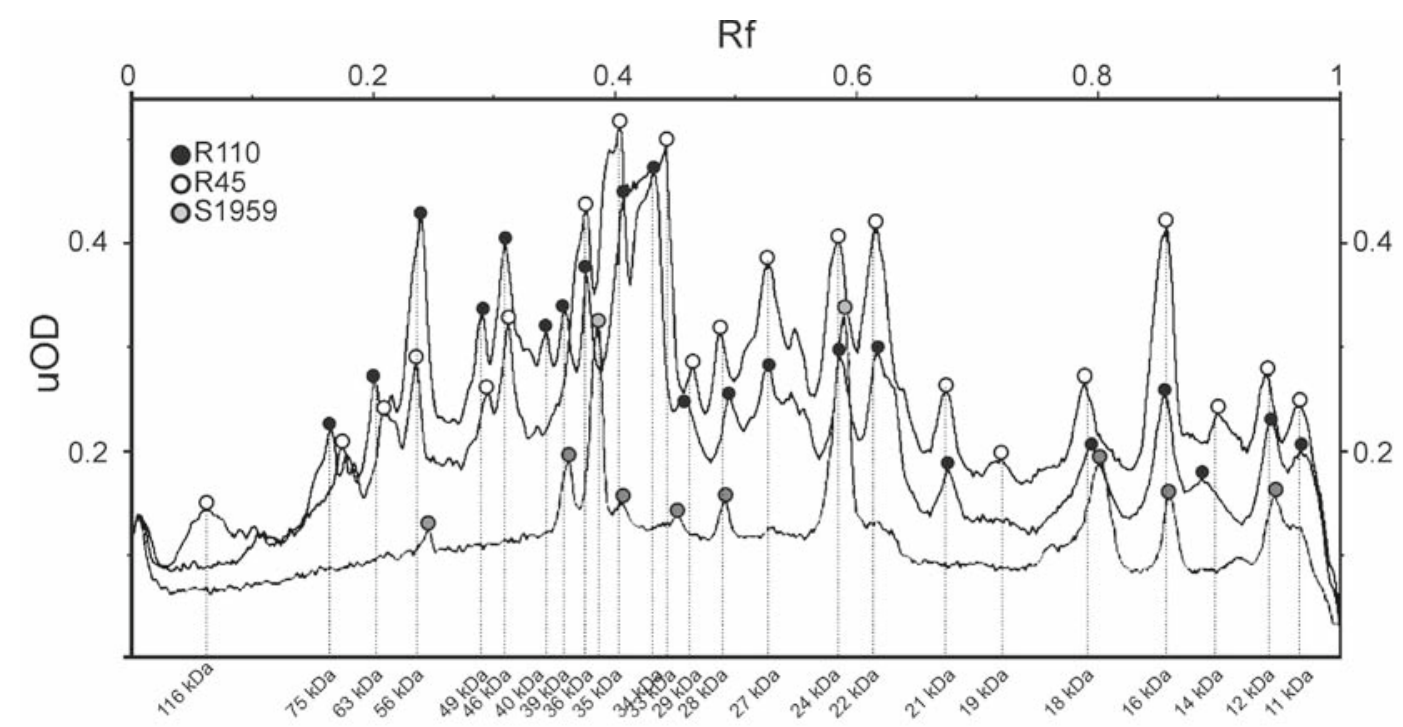

Fig. 1. The densitograms of OMPs from P. mirabilis. Molecular masses of the OMPs were analysed with Quantity One v. 4.0.1 software. 

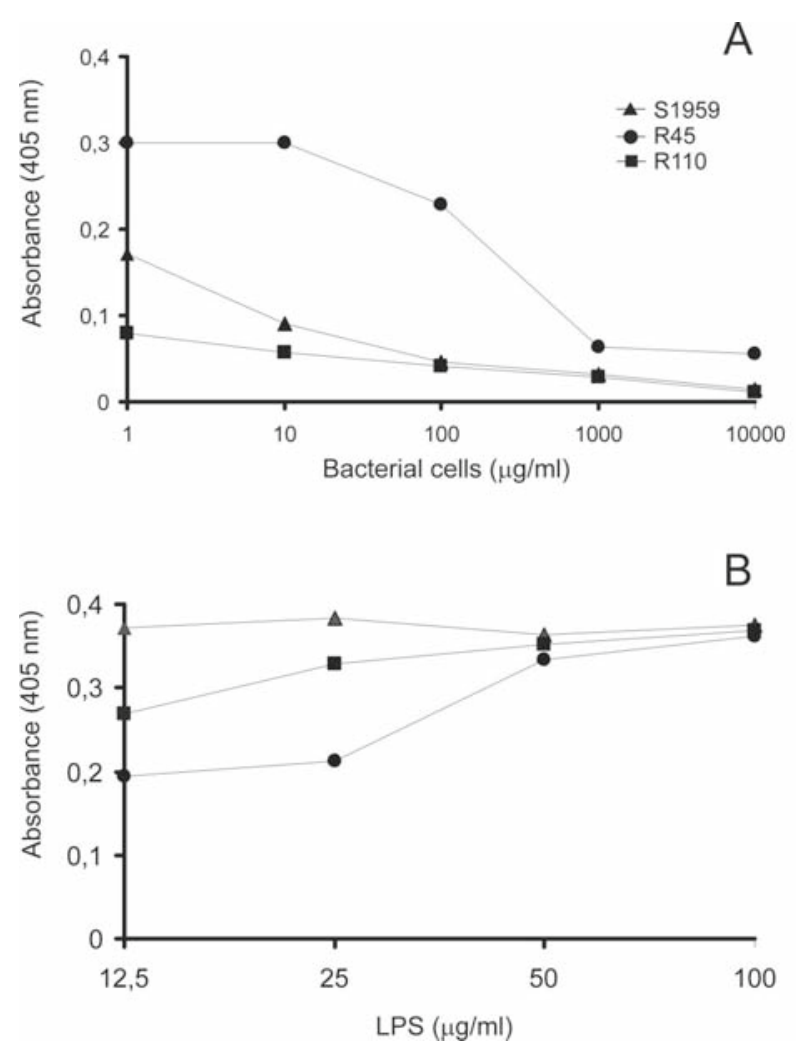

Fig. 2. Complement fixation by smooth and rough P. mirabilis dry masses (A) and lipopolysaccharides (B). The residual complement activity with antibody-sensitized sheep erythrocytes was determined as described in Materials and Methods.

C3 conversion resulted in MAC formation and bacterial lysis (Biedzka-Sarek et al. 2005). The conversion of native $\mathrm{C} 3$ to a series of low-molecular-mass fragments such as $\mathrm{C} 3 \mathrm{~b}$, iC3b, and $\mathrm{C} 3 \mathrm{c}$ was estimated by capture ELISA and crossed immunoelectophoresis. Smooth S1959 LPS was used to see whether there is a dose-dependent increase in C3c neo-epitopes (Fig. 3). A C3c increase was observed with S1959 LPS at concentrations of 0.083 to $83 \mu \mathrm{g} / \mathrm{ml}$. In the next experiment, the dose of LPS in the middle of the range, i.e. $10 \mu \mathrm{g} / \mathrm{ml}$, was used to compare C3c generation (Fig. 4). The S1959, R110, and R45 LPSs induced increases in the relative amounts of $\mathrm{C} 3 \mathrm{c}$ neo-epitopes above the control serum level in a statistically significant way $(\mathrm{p}<0.05)$. The potencies of the $P$. mirabilis S1959 and R110 LPSs to induce an increase in the amount of $\mathrm{C} 3 \mathrm{c}$ neo-epitopes did not differ, in contrast to R45 LPS, which had a lower ability (Fig. 4). This is in agreement with the total complement fixation test. R45 LPS was less effective in C binding than R110 LPS (Fig. 2B).

The crossed immunoelectophoresis method confirmed the capture ELISA data demonstrating that the native $\mathrm{C} 3$ is converted to $\mathrm{C} 3 \mathrm{c}$ and other low-molecular-mass fragments after exposure to the LPSs. The incubation of normal serum with the LPSs O10, S1959, R110, R45, R595, and fragments of LPSs resulted in the

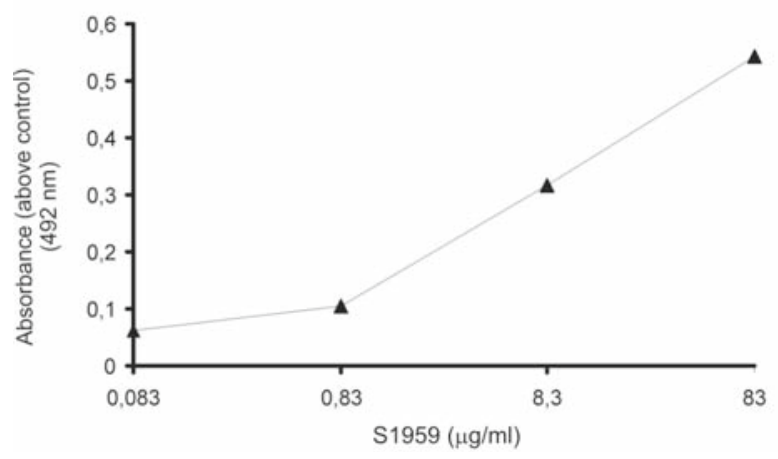

Fig. 3. C3 conversion under the influence of different doses of $P$. mirabilis S1959 LPS. Serial dilutions of $P$. mirabilis S1959 LPS in PBS were incubated for $45 \mathrm{~min}$ at $37^{\circ} \mathrm{C}$ in a water bath with 40 $\mu \mathrm{l}$ of serum ( $80 \%$ final concentration). Then a mixture of LPS and serum was diluted 1:2000 in ice-cold PBS supplemented with 10 mM EDTA, $0.02 \%$ Tween ( $\mathrm{pH}$ 7.3). From this, $50 \mu 1$ of solution were transferred to microtiter plates pre-coated with rabbit antihuman $\mathrm{C} 3 \mathrm{c}$ antibodies and the amounts of $\mathrm{C} 3 \mathrm{c}$ neo-epitopes were determined by HRP-conjugated rabbit anti-human C3c antibodies as described in Materials and Methods.

conversion of $\mathrm{C} 3$ to fast-migrating lower-molecularmass fragments, probably representing $\mathrm{C} 3 \mathrm{~b}, \mathrm{iC} 3 \mathrm{~b}$, and C3c. (Fig. 5A). The rabbit anti-human C3c antibodies were not specific to the $\mathrm{C} 3$ break-down fragments, but precipitated the native $\mathrm{C} 3$ as well. However, the $\mathrm{C} 3$ conversion by the LPSs was accompanied by a decrease in precipitates with native $\mathrm{C} 3$ and increased the amount of faster-migrating $\mathrm{C} 3 \mathrm{c}$ and other low-molecular-mass $\mathrm{C} 3$ fragments. $\mathrm{C} 3$ fragmentation was minimal with control serum alone (Fig. 5A panel 8). Regardless of the type of the polysaccharide structure, the $\mathrm{S}$ and $\mathrm{R}$ forms of $P$. mirabilis LPSs fragmented $\mathrm{C} 3$ to $\mathrm{C} 3 \mathrm{c}$ and were then detected by anti-C3c antibodies (Fig. 5A). P. mirabilis S1959, O10 (both S type), R110 (Ra), R45 (Re), and S. minnesota $595(\mathrm{Re})$ LPSs fragmented the C3 into smaller, faster-migrating components. The lipid A part of LPS O10 and the O-specific polysaccharide (F1S1959) also converted $\mathrm{C} 3$ to low-molecular-mass components.

To find the pathway involved in the $\mathrm{C} 3$ fragmentation induced by the LPSs, human C1q-deficient serum $(\mathrm{C} 1 \mathrm{qD}$, with only the antibody-independent classical pathway active) was used. In C1qD serum only two Re type LPSs, i.e. P. mirabilis R45 and S. minnesota 595, fragmented C3 (Fig. 2B panels 3 and 6). This result clearly shows that the antibody-independent classical pathway of activation is involved in C3 fragmentation by the Re type of LPSs. The presence of the core oligosaccharide (R110 LPS) and O-specific polysaccharides (S1959, O10 LPSs) inhibit that way of C3 conversion. Depleted of 2-keto-3-deoxyoctulosonic (KDO) residues, the lipid A part of $P$. mirabilis O10 LPS does not fragment the $\mathrm{C} 3$ complement component by the antibody-independent classical pathway of activation. This may suggest a role of KDO of the Re type of LPS in the above way of $\mathrm{C} 3$ conversion. 


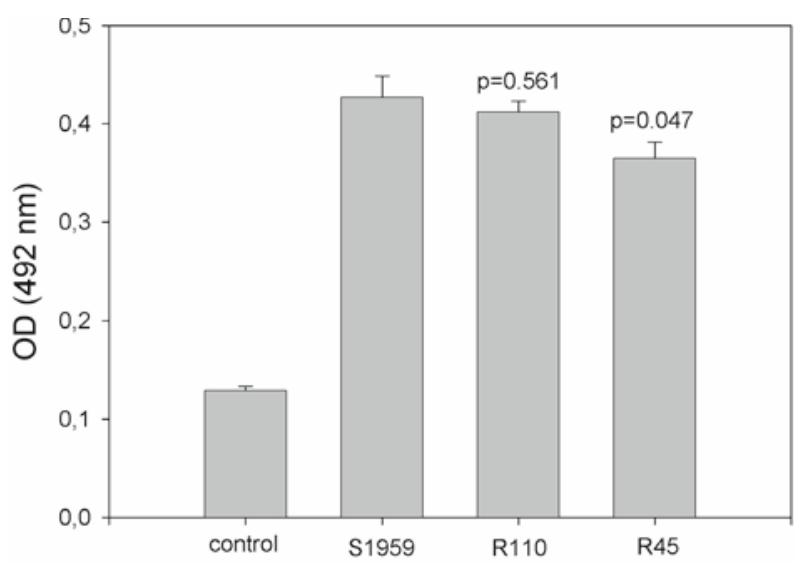

Fig. 4. Capture ELISA determination of $\mathrm{C} 3$ conversion to $\mathrm{C} 3 \mathrm{c}$ neo-epitopes in normal serum under the influence of the smooth and rough forms of $P$. mirabilis S1959, R110, and R45 LPS. $10 \mu \mathrm{l}$ of LPS $(1 \mathrm{mg} / \mathrm{ml})$ were incubated for $45 \mathrm{~min}$ at $37^{\circ} \mathrm{C}$ in a water bath with $40 \mu \mathrm{l}$ of serum ( $80 \%$ final concentration). Then C $3 \mathrm{c}$ neoepitopes were determined as described under Fig. 3 and in Materials and Methods. All values in this study are expressed as the mean \pm SEM from six measurements. The differences between variations (compared with S1959) were analyzed by ANOVA.

\section{DISCUSSION}

In the present study we showed $\mathrm{C} 3$ fragmentation to low-molecular-mass components containing $\mathrm{C} 3 \mathrm{c}$ neo-epitopes. C3 conversion was observed with P. mirabilis $\mathrm{S}$, Ra, and Re type LPSs, which differ in the polysaccharide parts linked to lipid A. C3 fragmentation with antibody-depleted serum (C1qD) showed that the O-polysaccharide and core oligosaccharide attached to lipid A Proteus LPSs prevented the complement components of $\mathrm{C} 3$ conversion by the antibody-independent classical pathway. Only the heptose-less Re type LPSs (P. mirabilis R45 and S. minnesota 595) fragmented C3 in the serum with the antibody-independent classical pathway $(\mathrm{C} 1 \mathrm{qD})$ active. These results are in agreement with data on the inhibition of complement-mediated hemolysis showing that heptose residues of the core oligosaccharide prevent the classical pathway of complement activation and the alternative pathway might start instead (Biedzka-Sarek et al. 2005; Gardiner et al. 1991; Vukajlovich et al. 1987). The heptose residues are present in the core oligosaccharide of the Proteus Ra types and the smooth form of LPSs.

Whether the electric is negative or positive appears to dictate which pathway of the complement system is activated. Negatively charged liposomes activate complement via the classical pathway, whereas those positively charged are responsible for complement activation via the alternative pathway (Chonn et al. 1991; Klink et al. 1998; Munstermann et al. 1999). The tested Proteus LPSs are positively and negatively charged (Różalski et al. 1997). Therefore, Proteus LPSs might activate complement by both pathways.

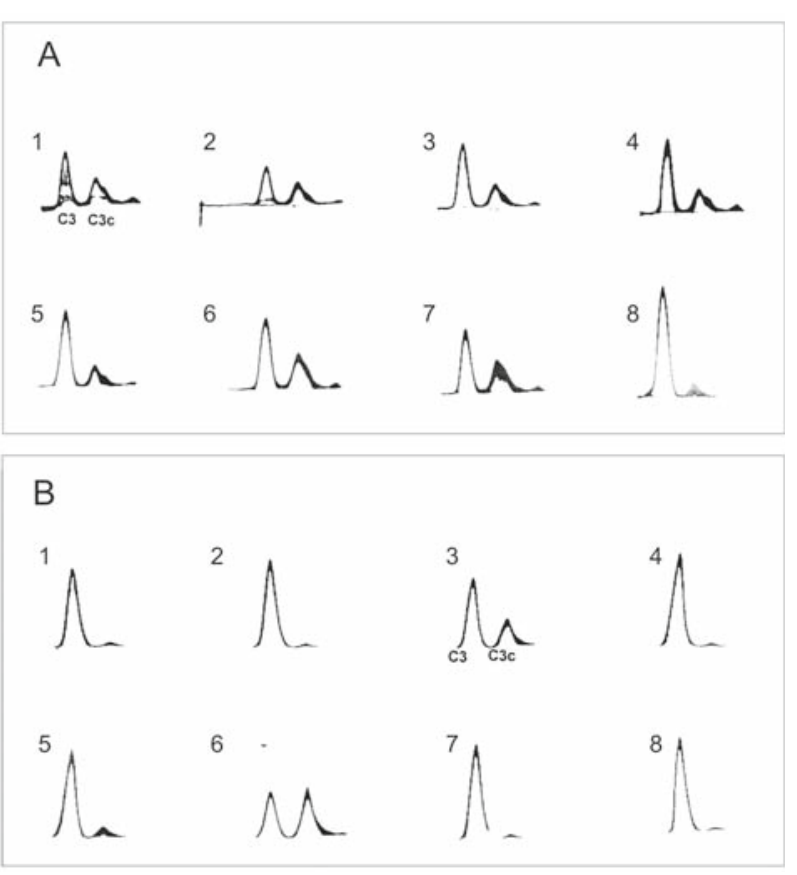

Fig. 5. Crossed immunoelectrophoresis with normal (A) and complement-deficient (B) human serum. Complement was activated for $45 \mathrm{~min}$ at $37^{\circ} \mathrm{C}$ by S and $\mathrm{R}$ forms of $P$. mirabilis and $S$. minnesota 595 LPS. C3 conversion was detected with rabbit anti-human $\mathrm{C} 3 \mathrm{c}$ antibodies as described in Materials and Methods. Complement-deficient serum (B), i.e. antibody-, C1q-, D-, P-, and MBL-deficient human serum, was supplemented with $10 \% \mathrm{C} 1 \mathrm{q}$ and that restored the classical antibody-independent pathway of complement activation (serum designated as C1qD). Panels: 1 S1959 LPS, 2 - R110 LPS, 3 - R45 LPS, 4 - F1S1959, 5 - lipid A O10, 6 - 595 LPS, 7 - O10 LPS, 8 - control serum alone. The anode is to the right.

The lower amount of $\mathrm{C} 3 \mathrm{c}$ neo-epitope generation by R45 than by R110 LPS correlates with the total complement binding by those LPSs in the hemolytic complement assay. Correlation in complement binding between lyophilized P. mirabilis S1959 bacterial cells and the respective LPS was not observed. The former effectively binds human complement, in contrast to the isolated S1959 LPS. This may indicate that OMPs exposed on the bacterial cell wall may prevent complement deposition on the core-lipid A part of S1959 LPS. This effect was not possible with isolated S1959 LPS.

Complement system activation is an important factor in the human defense system against bacterial pathogens (Burns and Hull 1998; Fischer et al. 1997; Joiner et al. 1986; Nawrot et al. 1995; Ram et al. 1998). The presence of O-polysaccharide on the surface of the P. mirabilis S1959 strain protected that strain from complementmediated lysis. The presence of a core oligosaccharide on P. mirabilis R110 (Ra type) was not sufficient to make that strain serum resistant. The serum resistance of smooth $P$. mirabilis $\mathrm{S} 1959$ (belonging to the O3 serogroup) is in line with those of the other smooth $P$. mirabilis $\mathrm{O} 10, \mathrm{O} 23, \mathrm{O} 30$, and $\mathrm{O} 43$ strains (Kaca et al. 2000). The importance of long-chain O-polysaccharide 
LPS protecting bacteria from human serum has also been observed by others (Joiner et al. 1986; Nawrot et al. 1995; Ram et al. 1998). One can postulate that the smooth LPS forms activate complement and deposit $\mathrm{C} 3$ on the long polysaccharide chains and in this way keep MAC formation at a distance from the bacterial cell membrane.

Well-known reports (Doroszkiewicz and Lachowicz 1989; Reeves 1995) and our own research (Cisowska et al. 2005; Futoma-Kołoch et al. 2006; Mielnik et al. 2001) have shown that many smooth strains demonstrate sensitivity to the bactericidal action of complement. The participation of OMPs has been suggested in bacterial serum-resistance phenomena by their inhibition of complement activation at the $\mathrm{C} 3, \mathrm{C} 9$, and C5b-9 levels (Biedzka-Sarek et al. 2005; Pilz et al. 1992; Prasadarao et al. 2002). The mechanism by which these proteins decrease the serum susceptibility of the strains is still not known. It is believed that minimal changes in surface loops of the outer membrane can have a profound impact on protective immune responses. It has been shown that OMPs from Klebsiella pneumoniae and Aeromonas salmonicida activate the classical pathway of the complement system by forming complexes with $\mathrm{C} 1 \mathrm{q}$, a component of the complement system (Alberti et al. 1993; Merino et al. 1998).

The $P$. mirabilis R110 strain with a Ra-type LPS, i.e. with a complete core oligosaccharide but devoid of the $\mathrm{O}$-antigen, and the $P$. mirabilis R45 strain (Re-type), a deeply rough strain with a truncated core oligosaccharide, produced about eleven OMPs more than the smooth $P$. mirabilis S1959 strain. In conclusion, the long O-specific polysaccharide part of LPS, probably in concert with OMPs, is responsible for the survival of the smooth P. mirabilis 1959 strain in human serum.

Acknowledgment: The work was supported by grants from Karolinska Institute, Sweden (for W. Kaca, A. Weintraub) and grant N N304 411433 from the Ministry of Science and Higher Education, Poland.

\section{REFERENCES}

Alberti S, Marques G, Camprubi S et al (1993) C1q binding and activation of the complement classical pathway by Klebsiella pneumoniae outer membrane proteins. Infect Immun 61:852-860

Amano K, Cedzyński M, Swierzko AS et al (1996) Comparison of serological reactions of Rickettsiae-infected patients and rabbit anti-Proteus OX antibodies with Proteus OX2, OX19 and OXK lipopolysaccharides. Arch Immunol Ther Exp 44:235-240

Andersson J, Ekdahl KN, Lambris JD et al (2005) Binding of C3 fragments on top of adsorbed plasma proteins during complement activation on a model biomaterial surface. Biomaterial 26:1477-1485

Becherer JD, Alsenz J, Lambris JD (1990) Molecular aspects of C3 interactions and structural functional analysis of C3 from different species. Curr Top Microbiol Immunol 153:45-72
Besucher HU, Brade V (1986) Lipopolysaccharides as complement inhibitors by complex formation with purified third complement component (C3). Immunobiology 173:41-55

Biedzka-Sarek M, Venho R, Skurnik M (2005) Role of YadA, Ail, and lipopolysaccharide in serum resistance of Yersinia enterocolitica serotype O:3. Infect Immun 73:2232-2244

Blatteis CM, Li S, Li Z et al (2004) Complement is required for induction of endotoxic fever in guinea pigs and mice. $\mathrm{J}$ Therm Biol 29:369-381

Bradford MM (1976) A rapid and sensitive method for the quantitation of microgram quantities of protein utilizing the principle of protein-dye binding. Anal Biochem 72:248-254

Burns SM, Hull SI (1998) Comparison of loss serum resistance by defined lipopolysaccharide mutants and an acapsular mutant of uropathogenic Escherichia coli O75:K5. Infect Immun 66:4244-4253

Chonn A, Cullis PR, Devine DV (1991) The role of surface changes in the activation of the classical and alternative pathways of complement by liposomes. J Immunol 146:4234-4241

Cisowska AG, Bugla-Ploskonska A, Gamian W et al (2005) Relationship between susceptibility to bactericidal action of serum and outer membrane protein patterns in E. coli $\mathrm{K} 1$ strains. Pol J Environ Stud 14:476-482

Doroszkiewicz W, Lachowicz TM (1989) Mechanism of antigenic variation in Shigella flexnerii bacilli. I. Selective lethal effect of normal sera on mixed population of $S$. flexnerii 1 b serotype and its antigenic 3b mutant. Arch Immunol Ther Exp 37:693-701

Fischer MB, Prodeus AP, Nicholson-Weller A et al (1997) Increased susceptibility to endotoxin shock in complement C3-C4-deficient mice is corrected by $\mathrm{C} 1$ inhibitor replacement. J Immunol 159:976-982

Nordin Fredrikson G, Truedsson L, Sjöholm AG et al (1999) DNA analysis in MHC heterozygous patient with complete $\mathrm{C} 4$ deficiency - homozygosity for $\mathrm{C} 4$ gene deletion and $\mathrm{C} 4$ pseudogene. Exp Clin Immunogenet 8:29-37

Futoma-Kołoch B, Bugla-Płoskońska G, Doroszkiewicz W et al (2006) Survival of Proteus mirabilis O3 (S1959), O9 and O18 strains in normal human serum (NHS) correlates with the diversity of their outer membrane proteins (OMPs). Pol J Microbiol 55:153-156

Galanos C, Luderitz O, Westphal O (1969) A new method for the extraction of R-lipopolysaccharides. Eur J Biochem 9:245-249

Gardiner JS, Keil LB, DeBari VA (1991) In vitro formation of complement activation products by lipopolysacharide chemotypes of Salmonella minnesota. Int Arch Allergy Appl Immunol 96:51-54

Garred P, Mollnes TE, Lea T (1988) Quantification in enzyme-linked immunosorbent assay of a C3 neoepitope expressed on activated human complement factor C3. Scand J Immunol 27:329-335

Holmskov-Nielsen JC, Jensenius B, Teisner B et al (1986) Measurements of C3 conversion by ELISA estimation of neo-determinants on the C3d moiety. J Immunol Methods 94:1-6

Hostetter MK (1993) The third component of complement: new functions for an old friend. J Lab Clin Med 122:491-496 
Hostetter MK, Gordon DL (1987) Biochemistry of C3 and related thioester proteins in infection and inflammation. Rev Infect Dis 9:97-109

Johnson U, Holmström E (1982) C3 fragmentation in human serum: formation of a mixed disulfide between $\mathrm{C} 3 \mathrm{~d}$ and albumin. Acta Pathol Microbiol Immunol Scand C 90:321-326

Joiner KA, Grossman N, Schmetz M et al (1986) C3 binds preferentially to long-chain lipopolysaccharide during alternative pathway activation by Salmonella monevideo. J Immunol 136:710-715

Kaca W, Literacka E, Sjoholm AG et al (2000) Complement activation by Proteus mirabilis negatively charged lipopolysaccharides. J Endotoxin Res 6:223-234

Kaca W, Roth R (1995) Activation of complement by human hemoglobin and by mixture of hemoglobin and bacterial endotoxin. Biochim Biophys Acta 1245:49-56

Klink M, Brzychcy M, Ziółkowski A et al (1998) The comparison of some biological activities of lipopolysaccharides obtained from smooth and rough Proteus mirabilis strains. Acta Microbiol Pol 47:141-151

Lachowicz TM, Doroszkiewicz W (1996) Sensitivity to complement as a factor of antigenic variation I Shigella flexnerii. Bull Pol Acad Biol Sci 44:255-260

Lachowicz TM, Doroszkiewicz W, Niedbach J (1999) Environment implication of lipopolysaccharide dependent normal serum sensitivity of Shigella flexnerii serotypes. Nova Acta Leopoldina 312:235-243

Laemmli UK (1970) Cleavage of structural proteins during the assembly of the head of bacteriophage T4. Nature 227:680-685

Merino S, Nogueras MM, Aquilar A et al (1998) Activation the complement classical pathway (C1q binding) by mesophilic Aeromonas hydrophila outer membrane protein. Infect Immun 66:3825-3831

Mielnik G, Gamian A, Doroszkiewicz W (2001) Bactericidal activity of normal cord serum (NCS) against Gram-negative rods with sialic acid-containing lipopolysaccharides (LPS). FEMS Immunol Med Microbiol 31:169-173

Munstermann M, Wiese A, Brabdenburg K et al (1999) Complement activation by bacterial surface glycolipids: a study with planar bilayer membranes. J Membr Biol 167:223-232

Murphy TF, Bartos LC (1989) Surface-exposed and antigenically conserved determinants of outer membrane proteins of Branhamella catarrhalis. Infect Immun 57:2938-2941

Nawrot U, Mokracka-Latajka G, Grzybek-Hryncewicz J et al (1995) Bactericidal activity of normal human serum against
Morganella, Proteus and Providencia strains. Acta Microbiol Pol 44:55-61

Ohta M, Okada M, Yamashina I et al (1990) The mechanism of carbohydrate-mediated complement activation by the serum mannan-binding protein. J Biol Chem 265:1980-1984

Pilz D, Vocke T, Heesemann J et al (1992) Mechanism of YadA-mediated serum resistance of Yersinia enterocolitica serotype O3. Infect Immun 60:189-195

Prasadarao NV, Blom AM, Villoutreix BO et al (2002) A novel interaction of outer membrane protein $\mathrm{A}$ with $\mathrm{C} 4 \mathrm{~b}$ binding protein mediates serum resistance of Escherichia coli K1. J Immunol 169:6352-6360

Ram S, Sharma AK, Simpson SD et al (1998) A novel sialyc acid binding site on factor $\mathrm{H}$ mediates serum resistance of silalylated Neisseria gonorrhorea. J Exp Med 187:743-752

Reeves P (1995) Role of O-antigen variation on the immune response. Trends Microbiol 3:381-386

Różalski A, Sidorczyk Z, Kotelko K (1997) Potential virulence factors of Proteus bacilli. Microbiol Mol Biol Rev 61:65-89

Sjöholm AG, Braconier JH, Söderstrström C (1982) Properdin deficiency in a family with fulminant meningococcal infections. Clin Exp Immunol 50:291-297

Taylor PW (1992) Complement-mediated killing of susceptible Gram-negative bacteria: an elusive mechanism. Exp Clin Immunogenet 9:48-56

Vinogradov E, Radziejewska-Lebrecht J, Kaca W (2000) The structure of the carbohydrate backbone of core-lipid A region of the lipopolysaccharide from Proteus mirabilis wild-type strain S1959 (serotype O3) and its Ra mutant R110/1959. Eur J Biochem 267:262-269

Vinogradov EV, Thomas-Oates JE, Brade H et al (1994) Structural investigation of the lipopolysaccharide from Proteus mirabilis R45 (Re-chemotype). J Endotoxin Res 1:199-206

Vukajlovich SW, Hoffman J, Morrison DC (1987) Activation of human serum complement by bacterial lipopolysaccharides: structural requirements for antibody independent activation of classical and alternative pathways. Mol Immunol 24:319-331

Westphal O, Jann K (1965) Bacterial lipopolysaccharides: extraction with phenol-water and further application of the procedure. Methods Carbohydr Chem 5:83-89

Ziółkowski A, Shashkov AS, Swierzko AS et al (1997) Structures of the O-antigen of Proteus bacilli belonging to OX group (serogroup O1-O3) used in Weil-Felix test. FEBS Lett 411:221-224 